\title{
GEOGRAPHY OF THE SURROUNDING COUNTRIES OF BULGARIA IN THE SCHOOL CONTENT OF THE SECONDARY STAGE
}

DOI: http://dx.doi.org/10.18509/GBP.2020.97

UDC: 37.016:91(497.2)

\author{
Stella Dermendzhieva \\ Tamara Draganova \\ „St. Cyril and St. Methodius” University of Veliko Tarnovo, Bulgaria
}

\begin{abstract}
In the present research is investigated the degree to which the surrounding countries to Bulgaria are considered in a normative section - laws, regulations, state educational standard, curricula. In the present study, using the qualitative research method, the document analysis technique is used as a data collection tool.

The analysis of the curricula in geography and economics in the presentation of the surrounding countries to Bulgaria (having land borders) is motivated by access to sufficient spatial knowledge at the global and local level and the formation of intellectual skills such as spatial thinking, spatial analysis and interpretation skills.

In this regard, in order for students to analyze and interpret the relationship between the human and the space for information, between borders, accessibility and practicality, it must start from the regional context, the geographical features of the surrounding countries to Bulgaria (in the geographical, socio-cultural and political-geographical attitude).

In today's world, the global and the regional attitudes and interactions require the recognition of the space and assessment and analysis of the spatial characteristics from the immediate environment to the global.

In this context the geography training will provide knowledge of space, spatial awareness, spatial analysis and synthesis skills in accordance with the near-far principle and will make people competent in the multidimensional and critical thinking skills required to understand space and its meaning.
\end{abstract}

Keywords: surrounding countries, borders, curricula, state educational standard

\section{INTRODUCTION}

The educational reform in Bulgaria from 2016 provoked the whole normative school system by law and put it in the conditions of gradual introduction of the procedural requirements for education, teaching and learning, defining peculiar changes in the educational system at the various infrastructural, content, administrative and institutional levels.

Education as an educational, educative and socializing process is a social phenomenon of great importance for anthropogenic development in the modern world. [1] The educational system in the context of the new Law for the Pre-school and School Education in Bulgaria is conditioned as a national priority, and the introduced state educational standards (DOS) as a reflection of the unified state educational policy for training as an essential, actual and permanent function of the society. 


\section{METHODS}

The methods by which the methodological interpretation is implemented is situational analysis, content-analysis, complex, integrative, research analysis and systematic and competence approach.

\section{DISCUSSION AND RESULTS}

A public district of vital importance and an existential mission, the interest and a necessity for the future of each nation is the training of the adolescents in the context of an educational reform, because ,, training helps both to preserve society and to change it”. [2]

The practical application and transformation transfer of students' knowledge into the reality is dynamic and fragmented in geography and economics training, which is set at a context minimum that does not imply activation of spatial thinking and motivated access to border information, geographical features of the surrounding countries in the context of natural-geographical, socio-cultural and political-geographical relations through the regional prism of training.

The research focus in this article is on training for the surrounding countries of Bulgaria (with land borders) in the upper secondary school stage at the basic educational degree at the normative level.

In the context of the normative statutory thesis that the country implements policies for improving the quality of the education and the determined principles and goals of the school education are the bearers of educational changes, we identify some of these principles and goals as a reflection of the issues examined in this article:

- ,orientation to the interest and the motivation of the child and the student, to the age and the social changes in his life, as well as to his ability to apply the acquired competences in practice;

- acquiring the competences necessary for successful personal and professional realization and active civic life in the modern communities;

- acquiring competences for understanding and applying the principles of the democracy and the legal country of law, human rights and freedoms, active and responsible civic participation;

- guessing the national, European and the world cultural values and traditions". [1] The study of the surrounding countries of Bulgaria is a direct meaningful and functionalefficient mechanism of introduction of the accents in the outlined principles and goals of the new Law on pre-school and school education.

The training for the surrounding countries is part of the state requirements of the school subject Geography and economics in the area of competence for the upper secondary stage of education - Geography of the continents and the countries. [3] The DOS for Geography and economics training is the first normative document that specifically regulates the study of selected countries (without specific examples) and a state policy to ,, form an objective worldview and geographical picture in everyone's lives, for countries and regions... and constitutes a generalized - synthesized basis of natural and socioeconomic geography (social) related to a specific horological territory". [4]

Two out of the four expected results of the training for knowledge, skills and attitudes cover and specify the training for the countries as a whole, without specifying the specific countries selected, which is explained by the type and content macro of the state document and setting a common applicable standard for requirements from the training 
in geography and economics for the three classes (V, VI and VII classes) at the upper secondary school stage of the basic educational degree (Fig. 1). The DOS clearly sets out the two expected results for the study of selected countries, belonging to the area of competence, as well as the links with the groups of key competences - 1, 3, 5, 6, 8 and 9.

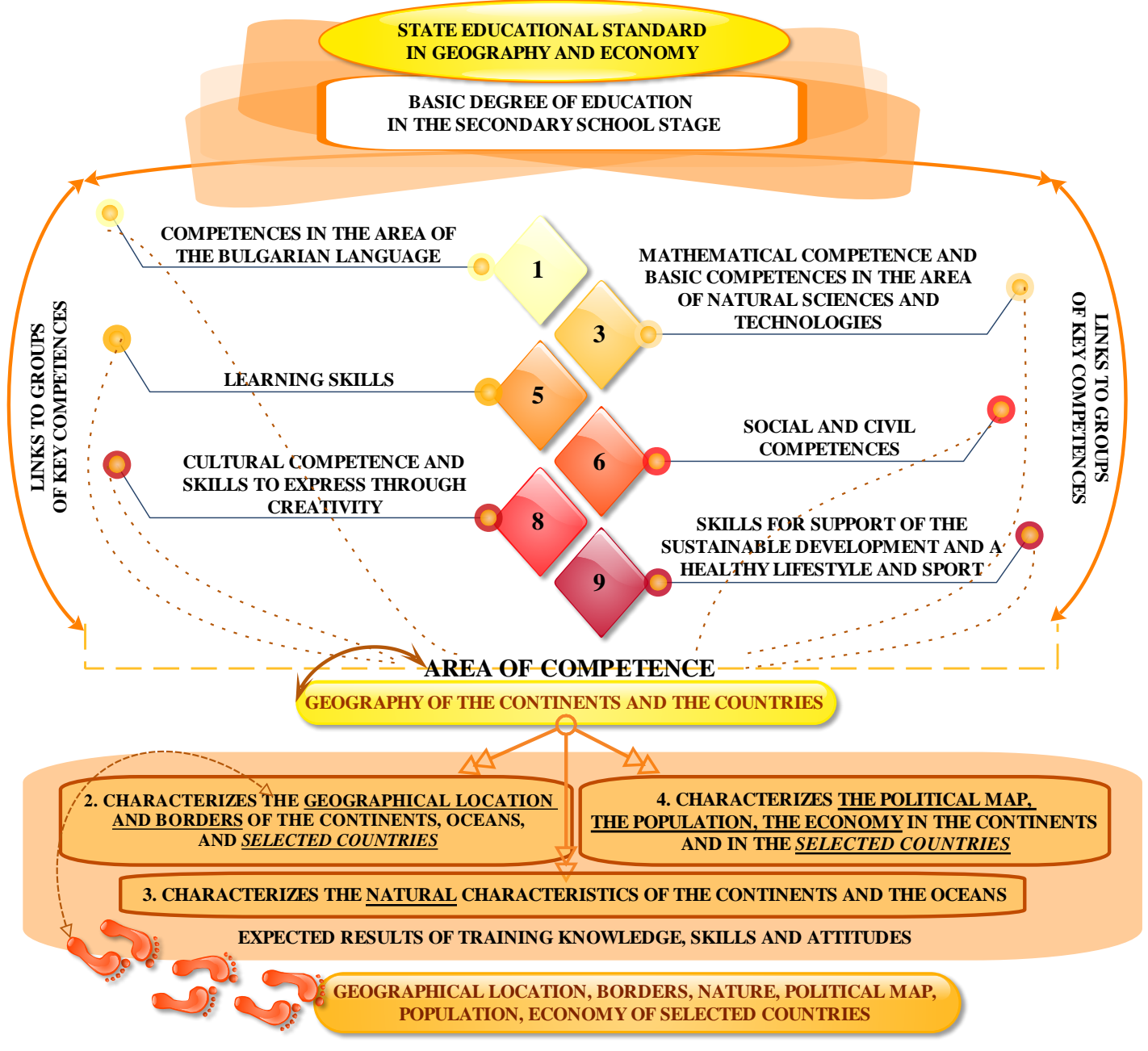

Figure 1. Graphical model of the study of selected countries on geography and economics in the upper secondary school stage in DOS

The imperative action is didactically legitimized by the active verb characterized, corresponding to the taxonomic group for application and the level of assimilation conceptual knowledge. The graphical model reveals both the specific and traditional school geography algorithm for characterizing a country in a specific sequence. The school geography training in school geography has ,,preserved the educational tradition of organizing and applying in the learning process an algorithm (rule) for characterizing countries”, which is a well-established and effectively proven ,educational-didactic technology and scientifically sound solution for studying country". [5]

The third expected result in the DOS is not specific to selected countries, but it is a compulsory step in the study of a country on a continent in which students are required to characterize the features of the nature. In a complete model of the rule for characterizing a country, the DOS does the didactic perspective: geographical location, borders, nature, political map, population, economy (Fig. 1). The state standard can be 
seen and by rule for characterization in a normative document, which reveals, imperatively enforces and procedurally establishes the rule ,as an educational technology with a specific construct, logical justification and hierarchically linked steps". [6]

The overall normative-content and structural-conceptual framework of the DOS has been transposed and transformed at the level of curricula in geography and economics for the upper secondary school stage (Fig. 2).

The area of competence we identify the Geography of the continents and the countries in all three grades of the upper secondary school stage - V, VI and VII class. [4, 7, 8, 9, 10] We find the study of the surrounding countries of Bulgaria for study only in two classes, but on one topic:

- VI class - theme 1: Geography of continents and countries; sub-theme 1.24.: Countries in Asia; Turkey;

- VII class - theme 1: Geography of continents and countries; sub-theme 1.16.: Balkan countries; $\underline{\text { Romania }}, \underline{\text { Serbia }}, \underline{\text { Macedonia }}$ Greece. $.44,8,9,10]$

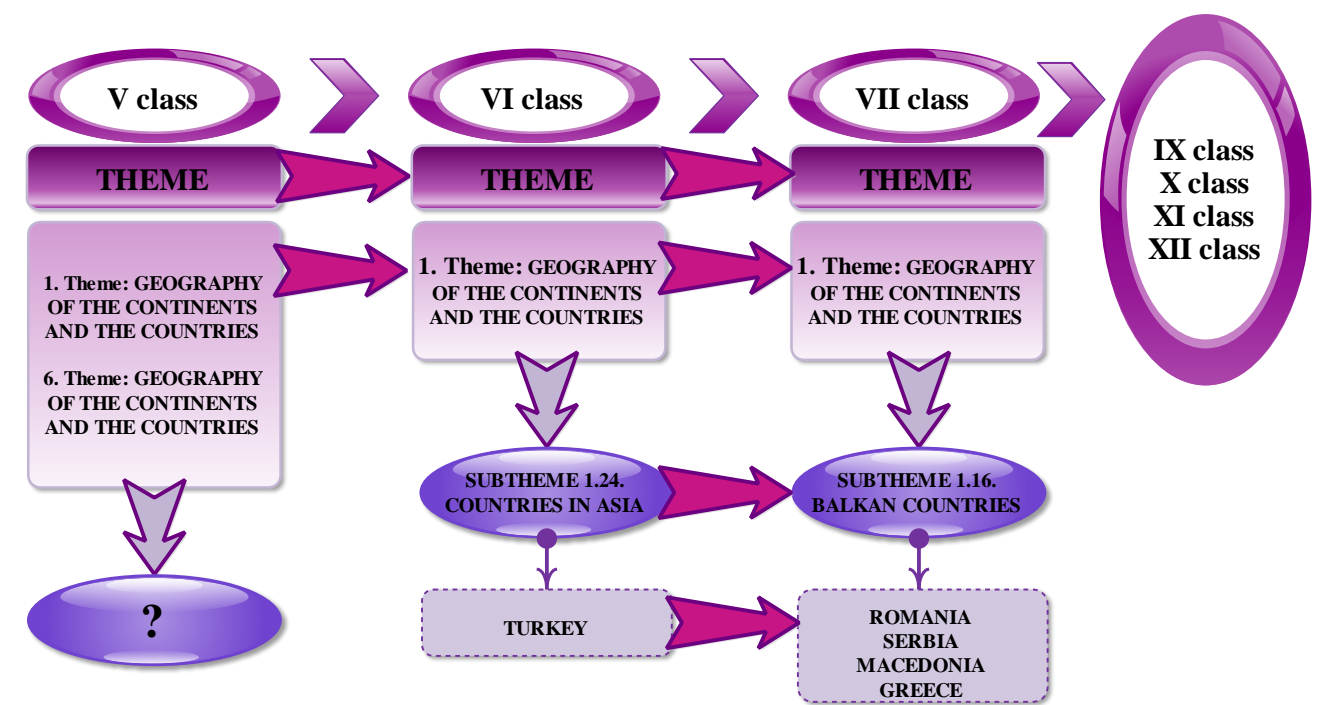

Figure 2. Topic Geography of continents and countries in the upper secondary school stage and location of surrounding countries by geography curriculum classes

The study of Turkey in the VI grade, outside the group of the other Balkan countries, is in the context of regional-territorial and typological principle in the training for the countries, as well as the specifics of economic development and the capital center. Turkey is determined for study in the continent of Asia - Countries in Asia, which has a scientific and didactic rationale. Studying a country, a typical representative for a continent in secondary school stage, is an educational tradition for school geography. The Balkan countries - Romania, Serbia, Macedonia and Greece are determined to study in VII grade, and are substantially localized to the second module of the three-module training: Europe - Balkan Peninsula - Bulgaria. All five neighboring countries of Bulgaria have the same required framework of the expected results (Table 1). 
Table 1. Systematic vision of the expected results in studying the surrounding countries in the curricula of geography and economics

\begin{tabular}{|c|c|c|c|c|}
\hline $\begin{array}{l}\text { CLASS } \\
\text { AND } \\
\text { THEME }\end{array}$ & SUBTHEME & $\begin{array}{c}\text { TOTAL } \\
\text { EXPECTED } \\
\text { RESULTS } \\
\text { BY } \\
\text { SUBTHEME }\end{array}$ & $\begin{array}{c}\text { COMPETENCES AS AN } \\
\text { EXPECTED RESULTS OF } \\
\text { THE } \\
\text { TRAINING }\end{array}$ & $\begin{array}{l}\text { NUMBER } \\
\text { AND } \\
\text { COUNTRIES }\end{array}$ \\
\hline $\begin{array}{l}\text { VI class } \\
\text { Geography of } \\
\text { the } \\
\text { continents } \\
\text { and the } \\
\text { countries }\end{array}$ & $\begin{array}{l}\text { Countries in } \\
\text { Asia }\end{array}$ & 1 & $\begin{array}{l}\text { 1. It characterizes the countries of } \\
\text { Japan, China, Turkey and the } \\
\text { Republic of Korea by rule. }\end{array}$ & $\begin{array}{l}1 \text { country } \\
\text { Turkey }\end{array}$ \\
\hline $\begin{array}{l}\text { VII class } \\
\text { Geography of } \\
\text { the } \\
\text { continents } \\
\text { and the } \\
\text { countries }\end{array}$ & $\begin{array}{l}\text { Balkan } \\
\text { countries }\end{array}$ & 3 & $\begin{array}{l}\text { 1. It compares the countries of the } \\
\text { Balkan Peninsula by area and } \\
\text { population. } \\
\text { 2. It characterizes the countries } \\
\text { Romania, Serbia, Macedonia and } \\
\text { Greece by rule. } \\
\text { 3. It presents a selected country of } \\
\text { the Balkan Peninsula in different } \\
\text { forms (text, poster, presentation). }\end{array}$ & $\begin{array}{l}4 \text { countries } \\
\text { Romania } \\
\text { Serbia } \\
\text { Macedonia } \\
\text { Greece }\end{array}$ \\
\hline
\end{tabular}

The common didactic feature of the expected results for the study of a surrounding country is the characterization by rule, which is valid to all five countries.

Specificity between the two classes is the presence of only one expected result in the study of a country, a typical representative of the continent of Asia, where in addition to Turkey, three other countries have been approved to study by rule - Japan, China, Republic of Korea.

The competencies as expected training results in the research of the four Balkan countries were composed on the basis of three requirements, which, in addition to what is known and applied in the previous class and the basic characterization of a country, by rule contains two specific expectations.

The expectation of the students to compare the countries of the Balkan Peninsula in terms of area and population is no practical orientation in transferring cognitive knowledge to direct reality and the real life. Undoubtedly, the activity of the verb, develops productive skills for comparing the statistical information of the countries and analyzing the data.

The third expected result requires students to represent a selected country across the Balkan Peninsula through a variety of forms - text, poster, presentation aimed at developing the intellectual and the practical skills, combined with creative ability development. The proposed electivity makes it possible to choose a surrounding country, focusing on the absorption of the borders and border checkpoints, the degree of accessibility and the features of providing opportunities for visiting natural-geographical and cultural sites, spatial interactions between the two nations and the development of the surrounding border regions, as well as the realization of common regional projects.

The curricula ensure the coherence and interconnectedness of the structural components of education for the countries surrounding Bulgaria in structural and substantive plan, and "the vertical systematization model guarantees success in the formation of comprehensive education, which is complex in nature and is acquired throughout the school education". [10] Vertical synthesis in terms of country characterization is, as a 
rule, a non-transient methodological-didactic tradition for school geography education, preserved and applied to new realities, which also bears the functionality of lesson organization and the structuring of learning content.

The study of surrounding countries is, as a rule, important to reveal knowledge of the „neighboring” space, spatial and specific awareness of the neighboring country, while respecting the principle of near to far by applying horologic-geographical analysis and synthesis, critical thinking and evaluation of opportunities to answer the questions Which site to visit? Where is it in the neighboring country? Why visit a geographical object?

The dynamic nature of social relationships, interwoven by complex interdisciplinary processes, provokes commentary on geography and economics training, and in particular the space of the surrounding countries of Bulgaria and the acquisition of competences, as well as the essence of the concept of ,geographical culture" and the variability of its possible definition and purpose.

The globalization process, taking place in the dynamic world of computerization, globalization and aggressive communication, places the geography of Bulgaria and our surrounding countries within the scope of the fundamental scientific plane. Each process of this particular territory takes place in the realized quadrant of the time/space coordinate system. This gives a leading role to geography and economics as a subject exploring the territorial diversity of life and the impact of socium on the geographical environment. One that provokes the importance of a scientific worldview. To those who master the ideas of the wholeness and diversity of the world, for its choro-chronological biography, written after the active attitude of multifactorial intervention, predetermined and outlined the direction for the formation of spatial (geographical) culture.

\section{CONCLUSIONS}

Changes and new realities are circumstances that define a new learning environment with adapted educational phenomena, processes and objects. The new principled educational basis is the orientation towards the interest and motivation of the students, the age and social changes in life, as well as the ability to apply the acquired competences in practice. According to the UNESCO Report on Education in the 21st Century („Learning Ability: Our Innate Wealth”): „The education drive up people closer to one another, as they are brought up to accept and understand common values... Therefore, the education system has a specific and hidden task of preparing everyone for this public role”. [12]

The training in geography and economics of the surrounding countries should be planned to form an idea of the essence, logic of relationships and the dynamism of processes in nature, society and economy.

The freedom to seek answers to the questions, to expand the meaningful and applied aspects of training for the surrounding country is ,, a reflection of specific methodologicaldidactic and pedagogical models, a consequence and normative projection of the school plans and programs that have been transformed into geography textbooks". [11] Each textbook is a work and creative product of the author's views on the content of the textbooks, which are the other procedural opportunity for studying the surrounding countries, to acquire a current-spatial and practical-applied vision for the surrounding countries of Bulgaria. 


\section{REFERENCES}

[1] Zakon za preduchilishnoto i uchilishnoto obrazovanie, 2015.

[2] Andreev, M. Protsesat na obuchenieto. Didaktika. S., UNI „Sv. K. Ohridski”, 1996.

[3] Naredba № 5 ot 30.11.2015 g. za obshtoobrazovatelnata podgotovka, 2015.

[4] Dermendzhieva, S., T. Draganova. Normativen vertikalen razrez i strukturno-sadarzhatelen model na „Geografiya na kontinentite i stranite” (V - X klas). Sbornik Godishna Universitetska nauchna konferentsiya, V. T., IK na NVU „Vasil Levski”, pp. 318-324, 2019.

[5] Draganova, T. Istoriografski pregled na pravila za harakterizirane na strana v uchilishnoto geografsko obrazovanie. International Scientific Refereed Online Journal with Impact Factor SocioBrains, 2018, ISSUE 41, pp. 36-46.

[6] Draganova, T. Rules for characterization of a country in the new geographic and economic textbooks - V grade. - B: International Scientific Refereed Online Journal with Impact Factor SocioBrains, February 2019, ISSUE 54, pp. 518 - 530. ISSN 2367-5721.

[7] Uchebna programa po geografiya i ikonomika za V klas (obshtoobrazovatelna podgotovka), 2015.

[8] Uchebna programa po geografiya i ikonomika za VI klas (obshtoobrazovatelna podgotovka), 2016.

[9] Uchebna programa po geografiya i ikonomika za VII klas (obshtoobrazovatelna podgotovka), 2017.

[10] Dermendzhieva, S., T. Draganova. Obuchenieto po „Geografiya na stranite” - vertikalni vrazki i sadarzhatelna makroramka po novite uchebni programi v balgarskoto uchilishte. Sbornik Nauchna konferentsiya „Balgariya, balgarite i Evropa - mit, istoriya i savremie”, V. T., UI „Sv. sv. Kiril i Metodiy”, t. 12, pp. 253-261, 2018.

[11] Dermendzhieva, S., T. Draganova. Situatsionen analiz na obuchenieto po geografiya na stranite na Balkanite po kriteriy stukturno-sadarzhatelna ramka. Sb. „Balkanite - ezik, istoriya, kultura, V. T., UNI „Sv. sv. Kiril i Metodiy”, t. VI, pp. 592-605, 2019.

[12] Доклада на UNESCO за образованието през XXI в. („Способността за учене: Нашето вродено богатство”), 1997. 